Comparative Philosophy Volume 6, No. 2 (2015): 14-34

Open Access / ISSN 2151-6014

www.comparativephilosophy.org

\title{
IT'S NOT THEM, IT'S YOU: A CASE STUDY CONCERNING THE EXCLUSION OF NON-WESTERN PHILOSOPHY
}

\author{
AMY OLBERDING
}

\begin{abstract}
My purpose in this essay is to suggest, via case study, that if Anglo-American philosophy is to become more inclusive of non-western traditions, the discipline requires far greater efforts at self-scrutiny. I begin with the premise that Confucian ethical treatments of manners afford unique and distinctive arguments from which moral philosophy might profit, then seek to show why receptivity to these arguments will be low. I examine how ordinary good manners have largely fallen out of philosophical moral discourse in the west, looking specifically at three areas: conditions in the $18^{\text {th }}$ and $19^{\text {th }}$ centuries that depressed philosophical attention to manners; discourse conventions in contemporary philosophy that privilege modes of analysis not well fitted to close scrutiny of manners; and a philosophical culture that implicitly encourages indifference or even antipathy toward polite conduct. I argue that these three areas function in effect to render contemporary discourse inhospitable to greater inclusivity where Confucianism is concerned and thus, more broadly, that greater self-scrutiny regarding unexamined, parochial western commitments and practices is necessary for genuine inclusivity.
\end{abstract}

Keywords: Confucianism, Manners, Etiquette, Ethics, Bias, Inclusivity

There has of late been increasing attention in professional philosophy to the need to better include non-western philosophies in our discourse. ${ }^{1}$ Greater inclusivity is needed both pedagogically and intellectually, as the abiding narrowness of the discipline's canon serves neither students nor the discipline itself. At least some of the difficulty in incorporating non-western philosophy into western-dominated discourses results from a kind of double bind. To gain inclusion, non-western philosophies need effectively to hook in to existing issues, interests, or paradigms in the dominant discourse; non-western philosophies need to offer something that addresses the

OLBERDING, Amy: Associate Professor of Philosophy, University of Oklahoma (Norman Campus), USA. Email: aolberding@ou.edu

${ }^{1}$ See, e.g., the recent online discussions of Park 2014. 
concerns and preoccupations western-trained philosophers find compelling and significant. However, where these philosophies do successfully hook in, this alone is rarely sufficient. Those scholars, for example, seeking to draw Buddhist no-self doctrines into contemporary discourses may be enjoined to explain just what Buddhist sources offer that Hume or Parfit do not already afford. ${ }^{2}$ Scholars working on virtue ethical interpretations of Confucian sources will need to demonstrate what the Confucians can philosophically accomplish that Aristotle cannot. Such is to say that even where non-western philosophical sources share common ground with western philosophies, that ground may yet be treated as fully occupied without them. They will simply seem surplus to requirements. Yet where non-western philosophies do indubitably deviate from what western-trained philosophers will find most familiar, where what they offer is transparently novel, this may generate resistance of a different order. For the more these philosophies appear to strike out into territories largely unexplored in western canonical sources or contemporary debates, the less "philosophical" they may seem to western-trained interlocutors. Failure to hook in to existing domains of inquiry or doing so in an unfamiliar style may awaken suspicion that here is something other than philosophy proper. ${ }^{3}$ The double bind for scholars who would promote interest in non-western traditions, then, can register as an importunate, impossible demand: Show us something we have not seen before, but be sure it looks well and truly familiar to us too.

In this essay, I present a case study. In my judgment, one of the most significant contributions early Confucianism offers philosophical ethics is its close and acute attention to the deep moral significance of ordinary good manners and etiquette. The Confucians were deeply committed to $l i$ 禮, here rendered as "manners" and "etiquette," making it a defining feature in their accounts of virtue. This essay, however, is not about $l i$ and I will not forward arguments about how western-trained ethicists could profit from engagement with Confucian commendations of manners and etiquette. For those who are interested, there is already an embarrassment of riches in the existing literature. ${ }^{5}$ Rather than rehearse what is already widely available, I want instead to address why this literature might be neglected; rather than

\footnotetext{
${ }^{2}$ That Buddhist philosophers developed insights into the instability of conceptions of personal identity millennia ahead of their western counterparts is insufficient to awaken substantial attention.

${ }^{3}$ Dotson 2012 well-captures and analyzes this phenomenon and its effect on diversity in philosophy.

${ }^{4} \mathrm{Li}$, typically translated as "ritual," most broadly encompasses traditional and conventional standards for conduct and comportment in recurrent social contexts. It governed high ceremony (e.g., funeral and memorial activity), conduct at court, and the myriad mundane activities of daily life, such as dining, greeting, receipt of gifts, and so forth. Those acquainted with contemporary work on polite standards will recognize a distinction between "etiquette" and "manners." While the former refers to local and culturally contingent rules for polite intercourse, the latter refers to the broad, often cross-culturally shared values that underwrite particular rules. Confucian $l i$ incorporated both of these and so in what follows, I freely employ both terms.

${ }^{5}$ Many works could be listed here, but some notable works particularly focused on $l i$ include: Kupperman 2002; Wong 2008 and 2014; Lai 2006; Sarkissian 2010a and 2010b; Olberding 2009 and 2015; and Stalnaker 2013.
} 
articulating what western-trained philosophers ought to see of value in Confucian treatments of manners, I want instead to discuss why they are unlikely to see it.

The Confucians' energetic commitment to etiquette and manners will, I expect, seem strange to most western-trained ethicists. But this, I argue, has far less to do with peculiarities in Confucian philosophical commitments than with a lack of selfawareness among western-trained philosophers regarding how their own idiosyncratic historical conditions, parochial discourse conventions, and professional culture inhibit appreciation of moral philosophy focused on manners and etiquette. This essay, then, is about these conditions, conventions, and culture, about the unacknowledged barriers to cultivating a more inclusive discipline that could welcome philosophy like that offered by the Confucians. To be clear, my argument is but a case study and thus necessarily limited in its scope. I only aspire to show why efforts to bring Confucian ethics to western-trained audiences are likely to fall on fallow ground. ${ }^{6}$ My critique is an effort to call attention to the fact that the soil itself needs amending if we are, minimally, to better incorporate non-western philosophies into the discipline and, maximally, to profit intellectually and philosophically from such efforts.

I hasten to acknowledge that my argument is fashioned in a somewhat polemical style. In explanation, I offer only a sense of exhaustion with supplication and a corresponding urge to critique. A ready abundance of work well attesting to the value of non-western philosophies has, from my vantage, been insufficient to win robust inclusion of these philosophies in the discipline. ${ }^{7}$ Moreover, I confess to personal exasperation with the way occasional efforts to bring non-western philosophy to wider attention too often transpire. However well motivated, these often simply reinforce the existing hierarchy, with the unfamiliar weighed and evaluated relative to how well it conforms to existing expectations and preoccupations. It is not, for example, uncommon in for $a$ where "east meets west," where efforts are made to bring Confucianism to the attention of scholars trained exclusively in western philosophy, to hear remarks that include prefaces such as: "What would make Confucianism more appealing..." or "What would make Confucianism work..." What follows such prefaces are typically recommendations that Confucianism sacrifice whatever is perceived as alien, regardless of how significant it may be for Confucianism itself. The most pronounced version of this I have encountered was a designated "western" philosophical respondent to a panel of papers on $l i$, or etiquette, who summarily announced that Confucianism would be "better" were it to "drop the whole $l i$ thing." Quite apart from its incurious hubris, this remark is akin to suggesting Kant would be

\footnotetext{
${ }^{6}$ To be clear, the practices of $l i$, or good manners, are so centrally important in Confucian ethics that exclusion of this element in what they offer is functionally and effectively to exclude Confucian ethics altogether from our discourse.

${ }^{7}$ E.g., by Brian Bruya's recent accounting, there are only eight Ph.D.-granting philosophy departments in the United States that include a specialist in Chinese philosophy among their faculty, a number that reflects the slim opportunities for students seeking to specialize, but more potently indicates how rare it will be that any philosophers will enjoy exposure to Chinese philosophy during their graduate study. For more on this data and additional reflections on the state of the field for Chinese philosophy, see Bruya forthcoming. It also bears emphasizing that among the non-western philosophical traditions, Chinese philosophy is the best represented in the discipline.
} 
acceptable if only he would not carry on so about reason. More broadly, one need only review the contents of the discipline's ostensibly generalist subject journals those devoted, for example, to ethics or to history - to see that receptivity to nonwestern philosophies remains low. ${ }^{8}$ Likewise, discussions of whether or how nonwestern philosophies should be included in the discipline too often pattern along the double bind described above, scrutinizing what these philosophies could possibly offer to conversations already underway without them. At least part of what these philosophies afford, I contend, is a way to recognize provincial idiosyncrasies in philosophical interests and practices, as well as the lacunae they may produce in western efforts to address the human condition or seek truth. The target of my case study-Confucian etiquette and manners-is, I think, but one such gap in contemporary ethics. ${ }^{9}$

My argument proceeds in four parts. I first provide a brief historical sketch of how manners and etiquette are positioned in western philosophical discourse. I then turn to discourse conventions prevalent in contemporary philosophical ethics, with the aim of showing how these appear generally uncongenial to study of manners. Third, I address the ways professional philosophy in the Anglo-American west may, as a sociological and cultural domain, incline practitioners away from serious philosophical interest in manners. I conclude by gesturing at how these features of western philosophical tradition and practice render it ill-suited for entertaining Confucian ethics.

\section{MANNERS AND WESTERN MORAL PHILOSOPHY}

As Judith Martin and Gunther Ghent observe, "Contemporary philosophers are largely innocent of etiquette" (Martin and Ghent 2001, 237). They have largely eschewed treating good manners as morally significant and indeed perhaps disdain etiquette as little more than "silly rules" (Martin and Ghent 2001, 238). However, we do well to recognize that even where western philosophy is concerned, this has not always been so: Aristotle remarks on the pleasing gait and voice timbre of the magnanimous person (Aristotle 1984, IV.3); both Seneca and Cicero actively instruct learners on the intersection of conventional good manners and the development of virtuous character; ${ }^{10}$ Hume closely observes the decorum in operation between host and guest, as well as writing extensively about sociability and good taste (Hume 1989, VIII.211); and Kant proffers rather elaborate recommendations regarding optimal

\footnotetext{
${ }^{8}$ E.g., in the 2010-2014 period included in the Philosopher's Index, of the 276 articles published on Confucianism, almost all appeared in specialist journals devoted to non-western philosophy. During this period, fewer than ten such articles appeared in the most highly ranked general ethics journals. The situation in journals devoted to the history of philosophy is even worse, with most appearing to treat "history of philosophy" as synonymous with history of western philosophy.

${ }^{9}$ I will not speak for philosophies outside my own specialty, but other obvious areas in which Confucianism excels in attending to subjects largely neglected in contemporary western philosophy include the ethics of family and relational identities, ethics of emotions, elder care, and the philosophical and ethical challenges of bereavement.

${ }^{10}$ For a study of both Cicero's and Seneca's remarks on decorum, see Sherman 2005.
} 
dinner party arrangements (Kant 2006, 179ff). ${ }^{11}$ Not caring about manners is, in western moral philosophy, of recent vintage.

Scholars often mark the break between western moral philosophy and manners as transpiring in the $18^{\text {th }}$ century and see the appearance of Lord Chesterfield's Letters to his Son as a signal provocation for the breach. ${ }^{12}$ While Chesterfield's Letters do not warrant the moral scorn they generated, ${ }^{13}$ because they were motivated in part by the desire to advise his son on strategies for socially ascending into "good company," they were decried. Chesterfield's Letters appeared to render explicit what many often suspected: Being socially pleasing could operate as a simulacrum of morality, a way to seductively engineer the good opinion of others and thereby gain social advantage. Samuel Johnson's biting response to the work-that it taught "the morals of a whore, and the manners of a dancing-master" (qtd. in Boswell 1953, 188)-vividly captures the suspicion into which polite social pleasantry of Chesterfield's sort was cast. Although sale of Chesterfield's Letters was brisk and interest in what he offered high among some, its popularity was seen by many in the intelligentsia as a scourge.

In some quarters, increasing disdain for the distorting and pernicious artifice of manners inspired a desire to recover purportedly more natural modes of conduct and praise for the "rustic." Rousseau provides an example of this. While not dismissing the worth of human companionship and community, Rousseau professes "distaste for the forms of human contact" both privileged and enforced in his time (Trachtenberg 2008, 211). Like Chesterfield's critics, Rousseau remarks upon the corrosive artifice and sly fakery of decorous norms, their capacity to render each opaque to each:

Before art had fashioned our manners and taught our passions to speak a borrowed language, our morals were rustic but natural, and differences in conduct announced those of character at first glance. Human nature, at bottom, was not better. But men found their security in the ease of seeing through one another, and that advantage, of which we no longer sense the value, spared them many vices (Rousseau 2012, 13).

In supplanting the natural, Rousseau averred, the ornamentation of conduct required by polite society also actively stifled individuation in favor of bovine conformity: One must follow custom, "but never one's own genius," acting always within the circumscribed constraints of "that herd called society" (Rousseau 2012, 13). The strictures of decorous convention thus ensured that one could neither be oneself nor well know others, for all would be concealed behind the "uniform and deceitful veil of civility" (Rousseau 2012, 13). The rustic here features, in contrast, as refreshingly

\footnotetext{
${ }^{11}$ For a rich taxonomy describing how Kant links dinner parties to moral sensibility, see Cohen 2008.

${ }^{12}$ See, e.g., Curtin 1985, 396ff.; Arditi 1994, 180-182; and Hamann 2000, 92-94. Chesterfield's Letters, written as counsel for his son and published posthumously in 1774, provide an ambitious compendium of the social mores of his day. Their instruction ranges from remarks on banal social practices to broader reflections on companionability.

${ }^{13}$ As Karen Stohr suggests, part of Chesterfield's reasonable interest in his son's decorous conduct is that "good manners make moral conduct more effective" (Stohr 2011, 16). Notably, Kant appears to draw inspiration for his reflection on dinner parties from Chesterfield (Kant 2006, 179).
} 
raw and transparent, authentically free from the distortions of enforced sameness and sociable opacity.

As Rousseau's remarks on the stifling of the individual intimate, embedded in skepticism about etiquette was an increased appreciation of individual autonomy, and this too would weaken any presumption that manners and morality are readily or comfortably joined. Influential philosophical work emphasized the individual's rational moral judgment as singularly authoritative. For example, Kant's insistence on the unparalleled importance of autonomy in moral agency entailed that "each person has a compass that enables 'common human reason' to tell what is consistent with duty and what inconsistent" (Schneewind 1998, 515). As Julia Driver observes, one effect of this was to disassociate morality from obedience: "On the new view, obedience to moral authority is obedience to the self" (Driver 2006, 621). While Driver focuses on declining trust in moral expertise, just as emphasizing individual autonomy depreciated deference to moral expertise, so too it undermined the authority of custom and convention, the stuff of good manners. The common wisdom, tradition, and shared practice that make up etiquette would be subordinate to rational autonomous judgment. Such judgment could, to be sure, assent to the practices of etiquette, but this would occur through the agent's own legislative powers rather than any reflexive or assumed expectation that one ought conform. ${ }^{14}$

Affirmative intellectual movements to prize natural authenticity and moral autonomy provided some reasoned basis for declining philosophical interest in manners. However, no account of this shift is complete absent attention to how interest in etiquette actively swelled in other quarters, largely as a result of changing economic conditions and the unprecedented social mobility they enabled. During the $18^{\text {th }}$ and $19^{\text {th }}$ centuries, traditional class structures were destabilized as never before, creating incentives for those seeking to move up the social ladder to adopt the manners of their "betters." Achieving command of etiquette practices was a way for those enjoying new economic prosperity to cultivate corresponding social capital. In particular, expansion of the numbers of women with leisure in the later part of this period gave rise to a publishing boom in etiquette manuals aimed at women newly able to assist in their families' social improvement through entertaining and hosting. As this new audience for social instruction emerged, with its interest in mastering the

\footnotetext{
${ }^{14}$ While I cannot assay the distinction here, I suspect that reliance on self-legislation by autonomous individual agents fundamentally misses important features of social practices and establishes a somewhat troubling hierarchy in which individual judgment always trumps social wisdom. To be sure, as I discuss later, independent judgments regarding social practices can be valuable routes to revising morally pernicious practices. Still, exclusively framing adherence to etiquette as a matter of individual decision evokes concerns. Some of these are deep concerns such as whether shared practice is meaningful in a world of lone agents, each deciding the terms of her own membership and sociality. Others attach to aspects of moral learning, such as whether we endorse a rather thoroughgoing hubris by vesting all authority in the individual. The worry in the latter case is that deciding for oneself that shared practice is wrong-shared practice representing the cumulative wisdom of generations of othersrequires great caution. This concern manifests in Confucian accounts, where considerable humility about one's own perspective is seen as the more prudent and morally responsible default position.
} 
"higher" social arts, the literature itself correspondingly shifted. ${ }^{15}$ Where commentary on character and virtue accompanied earlier models of the form, etiquette writing, now aimed principally at women, instead emphasized intricacies of formal rules and norms. Instruction on social virtue aimed at fitting readers for civic life was simply surplus to requirements given the abiding constraints of women's lives: "women were not active in the world and hence did not require instruction in worldly things in their books of manners" (Curtin 1985, 419). As audience and genre shifted, concern with etiquette became emphatically feminized, a preoccupation of "ladies," and etiquette instruction came to be derided as a "despised and trivial genre" (Curtin 1985, 418). Writing on etiquette increased apace, but it largely lost both audience and respectability among the intelligentsia.

This necessarily brief rehearsal of historical and sociological elements in removing etiquette from western moral philosophy surely elides many complexities, but my most immediate purpose is to note that there was a removal. Where manners and morality had been joined in western philosophical discourse, they came apart and they have, with few exceptions, remained apart. ${ }^{16}$ The historical reasons for this should worry us. The more active arguments against attention to manners, such as Rousseau's, hardly seem decisive for repudiating philosophical interest in manners. Prizing of the purportedly "rustic" and "natural" is itself prey to considerable suspicion, most commonly featuring as it does not among the "rustic" themselves but those enjoying sufficient social and economic privilege to romanticize it. The subject of individual autonomy has indubitably exercised a profound influence over developments in moral philosophy since Kant, but this too seems insufficient grounds for neglecting manners. Kant's own occasional close preoccupation with matters of etiquette suggests that no inevitable disconnection from etiquette must accompany serious attention to moral autonomy. Quite the contrary, insofar as etiquette practices operate as symbolic expressions of respect, a focus on autonomy and attendant notions of human dignity may enhance incentives to treat etiquette seriously. ${ }^{17}$ Most worrisome, that the decline of serious philosophical attention corresponds to shifting sociological conditions-conditions that rendered those most interested in etiquette just those least likely to enjoy influence in philosophical discourse, women and eager aspirants from the lower classes-should give us pause. That the privileged men who have historically populated philosophy's ranks abandoned etiquette just as the "lower orders" and women embraced it as empowering should, minimally, inaugurate misgivings about just why manners dropped from philosophical view.

These historical considerations suggest that we do well to hold in some suspicion recent philosophical neglect of the moral seriousness of good manners. However strange Confucian accounts of etiquette may appear to contemporary philosophical interlocutors, it may be we, not the Confucians, who are the oddities, our unconcern

\footnotetext{
${ }^{15}$ As Curtin argues, the courtesy book genre which preceded the etiquette manual regularly, and as a matter of course, blended instruction in etiquette with reflection on moral virtues (Curtin 1985, 395397).

${ }^{16}$ Notable recent exceptions to this include Buss 1999; Sherman 2005; and Stohr 2006 and 2011.

${ }^{17}$ Buss 1999 provides a compelling argument to this effect.
} 
with the moral dimensions of manners something many of the west's own philosophical forebears would have found puzzling. In addition to reflecting on the historical and sociological conditions under which etiquette lost favor in western moral philosophy, it is also important to acknowledge that contemporary western moral philosophy often operates under discourse conditions that ill fit it for consideration of etiquette.

\section{ETIQUETTE AND CONTEMPORARY PHILOSOPHICAL DISCOURSE CONDITIONS}

There is of course no uniform style of discourse that singularly marks contemporary philosophy. Nonetheless, there may yet be considerable implicit expectations regarding what good philosophy should accomplish. Among these expectations, the one most relevant to acknowledge in relation to moral accounts of manners is the priority we assign to developing arguments that are, as best we can make them, unassailable. While no argument succeeds in this, the expectation that we should nonetheless try inevitably influences the conditions under which discourse proceeds and indeed the terrain it will explore. Both how we talk and what we talk about may be constrained by estimations we make about the prospects for results that will be secure from ready challenge.

Seeking arguments that can withstand energetic critical scrutiny will, perhaps inevitably, direct attention toward just those regions within an argument's domain that seem most perilous, most liable to afford cover from which the critic may pounce. More generally, meeting hazards well can operate to display an argument's mettle. In contemporary philosophical ethics, this frequently takes the form of entertaining dramatic tensions between compelling, competing values or cases of moral conflict. Discourse often privileges for special attention hard cases that most test what an argument will entail and thus require its advocates to accept. ${ }^{18}$ Much attention is thereby directed toward cases where conflict is drawn to crisis, where competing values vie for dominance, and where there appears no good way out. Generally reliable rules are pressed into service to address the unusual circumstance that will ostensibly illuminate exceptions or expose the rule's vulnerability to problematically counterintuitive entailments. Fat men wedged in cave openings and imperiling their companions thus aid us in considering that troubling moral issue: When may I deliberately kill? Even where more commonplace aspects of moral experience are the target, the exceptional tends to prevail. Thus while we all must sometimes entertain whether to be truthful, it is to whether we must be so to murderers seeking those concealed in our basements that philosophy closely attends: "May I lie now?" we ask. The relatively thin contemporary literature on manners similarly inclines toward

\footnotetext{
${ }^{18}$ To be clear, I do not suggest that this is the only function hard cases serve. Pressing at these can, to be sure, illuminate otherwise opaque or unrecognized features of a moral theory. The trouble I identify, and address more later, occurs where preoccupation with hard cases functionally ever postpones fulsome examination of whatever more generally sound and compelling insight a moral view might offer.
} 
tensions and conflict, toward assaying the perils we court when we enjoin people to be polite.

The most basic form of the "hard case" in discourse about manners stems from commitments to autonomy, the perception that injunctions to abide by polite convention discourage the exercise of moral autonomy by supplanting individual moral judgment with conformity to imperfect social norms. Cheshire Calhoun registers this tension with reference to what she characterizes as a "socially critical moral point of view:"

When one adopts a socially critical moral point of view, one does not try to determine how people ought to be treated by investigating how they are treated, or how social conventions recommend they should be treated, or any other social fact of this kind. Instead, adopting a socially critical moral point of view means adopting a standpoint that enables one to evaluate the moral merit of established social norms and to recommend the moral principles that, ideally, would be embodied in our social norms. Adopting a socially critical moral point of view means being prepared to violate existing social conventions (Calhoun 2000, 252).

Strong advocacy of etiquette sits uneasily with valuing a socially critical moral point of view. We need not look far to find cases that illuminate tensions between what etiquette would require and what conscience can dictate: Need I shake hands with persons I find morally repugnant? Must I respond politely to socially acceptable gestures I judge to reinforce pernicious hierarchies? The general challenge here is whether I must treat conventional rules as binding when those rules defy my own considered moral judgments: In a contest between good manners and good moral conscience, what wins?

A related form of this concern often refracts through discourse regarding etiquette's social function. Enjoining adherence to contingent etiquette norms can register as a threat to social progress. For in suppressing exercises of conscience, etiquette suppresses dissent from the status quo that can helpfully challenge unjust or morally pernicious practices. In Sarah Buss' idiom, codes of manners, though they be widely accepted and broadly endorsed, can nonetheless be "codes of bad manners" (Buss 1999, 810). Rudimentary acquaintance with history assures us that our ancestors participated in practices we now consider morally wrong. Such practices change, when they do, where social consensus shifts, where what has heretofore been acceptable yields to more just practice. Rudeness and incivility can be the importunate rebels with a cause, with breaches of socially defined "good behavior" stimulating morally important revisions of shared conventions. Shifting conventional social norms is often important to moral progress, but the deeper our commitment to our contingent social practices, the less agile will be such shifts, the more belated our revisions of pernicious norms.

Concerns about conscience and social dissent enjoy most prominence in contemporary treatments of etiquette, I suspect, because it is here that we find our most familiar mechanisms for testing the worth of ideas: cases that challenge, conflict carried to crisis, and tension between competing values we must seek to resolve. The 
moral importance of etiquette, we risk suggesting, must be judged by how we answer the question: When may I be rude? Clearly this question is morally important. Nevertheless, it is problematic where it summons the lion's share of attention. Most fundamentally, the question already presupposes a model of moral conduct at odds with how manners typically work. Behaving politely will most often and in most circumstances not issue from self-conscious choice and decision, but out of acquired habits in speech, conduct, and demeanor. One may of course select what habits one will cultivate, but even here, more often one's habits will result from accession to conventional practices widely recognized and practiced in one's community. So too, rudeness will more often result from poor habituation, inattention, or competing claims on finite energies than from deliberate, purposeful rule-breaking. Such is to say that manners may not be a moral territory that can be well-mapped with the tools most often employed in contemporary discourse. More basically, to the extent that contemporary philosophical practice inclines us to hasten to locate the most perilous areas within an argument's domain, it may suppress exploration of manners altogether. For manners may well be, and indeed I expect they are, a terrain with an overabundance of perils. They are, in other words, endlessly and ever assailable. Comprised of contingent and culturally peculiar custom, originating in fallible and imperfect tradition, manners will always and persistently present problems. To the extent, then, that contemporary expectations of philosophical discourse direct effort and attention toward unassailable conclusions, it will depress attention to the practices of good manners.

I hasten to acknowledge that there are of course theoretical approaches available in contemporary western moral philosophy that steer away from preoccupation with dramatic tensions and cases, most notably virtue ethics and care ethics, both of which scholars have argued share important resemblances to early Confucianism. ${ }^{19}$ However, although these moral theories appear more immediately congenial to addressing manners, neither undertakes the close and sustained attention to polite practices seen in Confucianism. That is, even while many contemporary ethicists do selfconsciously incline away from preoccupation with hard cases, this has not yet inclined them toward close attention to manners. The reasons for this are surely several, but the comparably few works on manners found in contemporary scholarship indicate one: perceptions regarding what philosophers care about.

Strikingly, where contemporary ethicists speak to manners, they often inaugurate discussion with apologetics pitched to anticipate and answer the charge that their subject simply does not warrant philosophical attention. More basically, they appear to assume that their fellow philosophers may pre-emptively refuse to follow them on excursions into manners. For example, Buss observes, "Many philosophers, however, seem to take it for granted that manners lie outside the scope of morality. They assume that doing one's moral duty is one thing, being polite quite another" (Buss 1999, 796). Nancy Sherman more emphatically sounds a similar note: "Philosophers

\footnotetext{
${ }^{19}$ For treatment of Confucianism and virtue ethics, see, e.g., Slingerland 2001; Van Norden 2007; Yu 2007. For Confucianism and care ethics, see Li 2000 and Rosenlee 2006.
} 
have been quick to dismiss manners and comportment as optional trim on moral character, and in some cases, as mere priggish conventions that have little bearing on genuine virtue" (Sherman 2005, 60). And, in work on civility, Calhoun identifies "intimate associations with etiquette or good manners" as one of "three strikes" against considering civility a virtue (Calhoun 2000, 251). Similar observations feature where ethicists undertake close study of virtues that, by their nature, inevitably incorporate performance of etiquette practices. In work on agreeableness, Kristján Kristjánsson notes, "Many philosophers would complain that such dallying with demeanor and niceties lacks any real moral ballast" (Kristjánsson 2006, 36). Writing about tact, David Heyd concedes that tact "at first sight seems quite marginal and of little philosophical interest" (Heyd 2008, 218). In sum, readers interested in philosophical treatments of manners quickly learn that a discourse convention of this literature is to acknowledge that taking manners seriously is a venture undertaken in defiance of what most philosophers will count important. There is, I think, much that is correct in these ethicists' perceptions about the interests of their peers, but this simply invites us to ask why this would be so.

\section{PHILOSOPHY AND THE ICONOCLAST POSE}

That contemporary western-trained philosophers might doubt the philosophical bona fides of etiquette is likely explained in part by the historical conditions I briefly canvass above. Such doubts, however, also find support in the informal ways in which the philosopher's social identity is currently constructed. Such is to say that estimations of what counts as "philosophically interesting and important" may well have sociological features. I have argued elsewhere that the social identity of the philosopher is currently constructed in ways at odds with good manners (Olberding 2014). Let me briefly reprise this argument as it bears on receptivity to treating etiquette and manners as "philosophically interesting."

In his work on social self-presentation, Erving Goffman argues that professions tend to forward a group social identity by implicitly encouraging members "to incorporate and exemplify the officially accredited values of the society" (Goffman $1959,35)$. A social group is meaningfully constituted by its members' accession to a body of shared values. To be in the group is to endorse its values, but also, and significantly, to signal this endorsement in one's behavior and comportment. The group thus constitutes itself as group in part through the development of a recognized symbolic "pose," external markers of membership that may include characteristic, identity signaling modes of speech, interaction, comportment, or even dress. ${ }^{20}$ Signaling one's membership to others transpires both from intellectually acceding to shared group values and from enacting what symbolically signals those values in

\footnotetext{
${ }^{20}$ That philosophers do have such an externalized, visible pose is, I think, often evident at conferences, where one can sit in a hotel lobby or bar and make sport by trying to identify which of those passing by are philosophers. Indeed, I have overheard philosophers at conferences doing just this, using cues offered by dress, physical demeanor, and modes of speech to spot others of "their kind" in a mixed social space.
} 
one's social self-presentation. ${ }^{21}$ The profession of philosophy, I suggest, often inclines toward forwarding a social identity and pose for philosophers that implicitly pitches itself against caring about ordinary good manners. Both how philosophy itself is characterized and the symbolic social behaviors that attend this characterization are such as to reduce receptivity to taking manners seriously.

The "officially accredited values" of philosophy-those values that distinctly mark philosophers out as members of a shared intellectual and social guild-are perhaps most often characterized by philosophers themselves as having no "officially accredited values." Efforts to describe what philosophy is and thus what philosophers do often emphasize its critical spirit and, correspondingly, the intellectual independence of the philosopher, his ability to stand free of the unexamined conventions and commitments by which others operate. ${ }^{22}$ Moreover, because he does stand free, he uniquely welcomes plain speaking-the better to get at truth-and cares little for decorous pleasantry or unnecessary, muddy indirection. While I think this version of the philosopher's social identity is of recent vintage, it seems to derive some of its power by drawing on characterizations of western philosophy's originating exemplar.

Socrates looms large as western philosophy's first and most potent exemplar. He challenges those in power, ostensibly indifferent to the personal costs he thereby incurs, and explicitly disavows concern with the preoccupations of ordinary people. He openly defies and sometimes mockingly skewers the unreflective, unexamined "truths" by which others operate. He speaks truth to power and cares not about any offense he may thereby provoke, for he is valiantly unbound by the opinions of others or by social convention. He doesn't even wear shoes! This is of course an unsubtle, ham-fisted sketch of Socrates, but it is one that simplifies into romantic heroic form a figure under whose influence western philosophers have long labored. And shades of just this ham-fisted figure frequently feature in how contemporary philosophers describe their own activities and indeed the persona philosophy purportedly requires.

As Robert Solomon observes, philosophy entails a happy willingness to enact "a profound kind of freedom" ungoverned by the preoccupations and expectations of wider society (Solomon 2003, 7). Graham Priest's account of philosophy is perhaps most fulsome in characterizing this freedom. Priest argues that philosophy is essentially "subversive" and that, for the philosopher, "there is nothing that is sacrosanct, no criticism that is beyond the pale" (Priest 2006, 201). Although there is surely some justice in this characterization of philosophy's intellectual orientation, it also clearly sometimes operates as a social pose in the sense that Goffman limns, a way of marking out the philosopher from others, a mechanism by which philosophers assert and legitimate a shared identity. This is most evident in how philosophers

\footnotetext{
${ }^{21}$ To be clear, the phenomenon Goffman describes most often transpires below conscious awareness, with members of a group replicating the social pose of the group absent any substantial awareness that they are doing so.

${ }^{22}$ I here employ male pronouns for philosophers advisedly, as I suspect that the male skew in the demographic profile of philosophy may be encouraged by the pose I here describe. An argument to that effect is offered in Olberding 2014.
} 
sometimes valorize their purportedly radical freedom in order to distinguish themselves from other academics. Priest, for example, identifies the bold willingness to question anything as the distinguishing trait of the philosopher. Members of other disciplines - he cites science, religion, and history as examples - are not "allowed to question" so freely (Priest 2006, 201). The force of this as pose is evident if we press a bit at the comparison to other disciplines.

It seems to me debatable whether other disciplines do indubitably possess unchallenged or unexamined commitments, at least in any sense meaningful for readily distinguishing philosophy from other disciplines. ${ }^{23}$ Historians do not, to be sure, query whether "other historians have minds" (Priest 2006, 201), but there is a considerable gap between historians' failure to query this and their having significant, "sacrosanct" commitments they decline to examine. ${ }^{24}$ More directly, no reader of contemporary scholarship in history is likely to conclude that historians systematically fail to achieve the features Priest associates uniquely with philosophy: Historians too "challenge things which everybody else takes for granted, or whose rejection most people do not countenance;" studying history is, for many American students at least, deeply "unsettling" and can leave learners feeling "that they have had the rug pulled out from under them;" and historians do seem to perform work of "universal import," if we include in this the significance of developing historical sensibilities about human institutions and the human condition (Priest 2006, 202-203). The only feature Priest associates with philosophy that historians clearly fail to fulfill is telling: "philosophers make a habit in seminars and conferences of attacking the views put forward by the speaker, in a way that would be considered unseemly in other disciplines" (Priest 2006, 203n.9). That is, philosophers behave in ways others find rude.

Philosophy's ostensible commitment to free inquiry produces a pose and discourse style unbound by the polite conventions on which others operate. This is evident in how philosophers describe their work, their proclivity for employing agonistic metaphors to capture philosophical activity, metaphors ranging from the ubiquitous "attack" to those suggestive of cowboys at the OK Corral, such as Priest's claim that philosophers have always "shot at religions, political systems, and public mores" (Priest 2006, 202), or Solomon's regretful observation of philosophy's "gunslinger" discourse style (Solomon 2003, 9), or the "argument as combat" model incisively critiqued by Helen Beebee (Beebee 2013, 66). ${ }^{25}$ Indeed, philosophy's

\footnotetext{
${ }^{23}$ More debatable still is whether philosophers enjoy an epistemic vantage from which such a conclusion could be securely reached.

${ }^{24}$ I do not take it as prima facie evident that sacrosanct commitments are implicitly endorsed wherever a discipline fails to address some question, much less a question not clearly within its traditional disciplinary purview. Moreover, a historian might well charge philosophy with having a "sacrosanct" commitment to its own purportedly ahistorical freedom for its persistent failures to query the historical contingencies influencing the trajectories of inquiry it has pursued.

${ }^{25}$ One obstacle to developing more congenial conversational models is, as Beebee compellingly argues, an inability or unwillingness to separate critical content from aggressive style. As she observes, the former can well exist without the latter, though they are too frequently taken as synonymous in discussions of philosophical interactional style.
} 
discourse practices are such that critics of this style are left to issue reminders that "philosophy isn't Fight Club" and explicitly request pedestrian polite standards (Chalmers undated). For it is no given that philosophers know better than to roll their eyes, "make faces," and act "incredulous" when entertaining each others' work (Chalmers undated). While Beebee and Chalmers represent a countertrend to agonistic discourse style, in the contest between civility and combat, combat appears to be winning. ${ }^{26}$ To be sure, this at least does distinguish us from the historians. ${ }^{27}$

Where we take measure of how the social identity and pose of the philosopher is currently constructed, it seems, at least to me, that the much-vaunted critical spirit of philosophy is insufficiently critical of its own conceits. There are considerable existential perils here. There may be no firmer chains than the mistaken, confident conviction that one is uniquely free. So too, there is considerable bathos in believing oneself like Socrates while being merely and rather prosaically rude. These perils are significant and we should be unhappily wary when characterizations of our distinctive work reduce to our practicing styles of interactions others find unpleasant. However, my interest is in registering these issues as a way to capture why finding manners "philosophically interesting" is at odds with a persona too often actively and explicitly cultivated in professional philosophy.

In its most egregious forms, the philosopher's pose leads to blunt valorization of a rather juvenile rebellious spirit out of which a philosopher should:

taunt the prudish and prim, ridicule the conventional and boring, outrage the pious and conformist. The cultural tradition that falls under this description sees itself as in favor of art, freedom, creativity, spontaneity, playfulness, life, and experience; it casts itself as standing against stifling social norms and dull conformity. It is given to provocation, controversy, and shock tactics. Accordingly, it is often pilloried and persecuted, and of course misunderstood. It does not see itself as against morality as such, but it does view conventional pieties with a beady and skeptical eye. It is on the lookout for hypocrisy, dogma, intolerance, suppression, and sheer dullness of spirit (McGinn 2013).

\footnotetext{
${ }^{26}$ In my view, efforts to promote more genial modes of interaction in the discipline have been damaged by the harsh responses these efforts too often receive. We seem to have achieved exquisite nadir in the profession when taking a pledge to be professionally civil is construed as the opening bell on a pugilistic cagematch (See Schmidt 2014). That many philosophers resist this has not yet been enough to substantially alter the profession's problematic climate. It is of course possible that the heat surrounding calls for greater civility issues in part from just the social identity issues I assay above. Insofar as philosophers define their distinctive identity by extolling agonism as "our way," reduction of the discipline's pugilism may register as an existential threat. Beebee intimates something like this, as she notes that arguments indicating that women may dislike the discipline's aggressive style are sometimes received as insulting to women-that is, philosophy is so identified with this style that to not like it is tantamount to not liking, or being capable in, philosophy. See Beebee 2013.

${ }^{27}$ While I do not make this argument explicitly, this proclivity for identifying philosophical activity with a merciless, agonistic discourse style likely promotes the imperative to seek the unassailable: Where one knows that one's interlocutors will "pull no punches" in forwarding critique, venturing into the assailable will seem unappealing. Put more plainly, the purportedly "unbound" discourse style of philosophy may yield much philosophy that is intellectually cramped and constricted by the defensive crouch gunslinging renders safest.
} 
Reflections such as this not only dismiss the stuff of convention infusing manners, they actively promote enmity toward it and contempt for those who might care about it. I cannot surmise how widely shared this more extreme view of philosophical activity is among philosophers, but we do well to recognize the continuum between more benign expressions of the philosopher's "unique freedom" and a more ambitious, self-valorizing arrogance that imagines the philosopher ever pitched against an unthinking herd. Where prideful agonism and reflexive, incurious scorn for ordinary social norms enjoy some currency in how philosophers conceive themselves and their activity, serious philosophical discourse about manners will be suppressed.

It may of course be objected that even if the social identity of the philosopher promotes discourse styles that discard or even disdain conventional good manners, this need be no barrier to our taking a theoretical interest in manners; behavioral indifference to etiquette need not transmute into intellectual indifference. ${ }^{28} \mathrm{I}$ am, however, skeptical that such a division is easily maintained. Indeed, believing we can embrace an intellectual interest in politeness while practicing aggressive, rude styles of discourse strikes me as dreadfully naïve. ${ }^{29}$ For it appears but a refinement in the myth of our intellectual independence and freedom: where ordinary mortals might find their customary habits and practices exercising an influence over their attitudes and interests, the philosopher is immune. More concretely, we ought not neglect the reality that philosophers are made, not born. They are produced in and by socialintellectual atmospheres and, as Goffman argues, desire to secure a place within a social group amplifies incentives to appear well-fitted: The role-seeker will want to demonstrate a "sacred compatibility between the man and his job" (Goffman 1959, 46). We thus should not expect philosophers developing their identities within a guild that practices disdain for ordinary mannerly conventions to intellectually embrace a domain so removed from the way their guild defines itself and structures its distinctive pose. ${ }^{30}$

\section{THE CONFUCIAN TERRITORY}

Where we acknowledge the limitations of western philosophy regarding manners and etiquette-its historical shifts, discourse conventions, and social identity-it is no wonder that a western philosopher encountering Confucianism should think it good to "drop the whole $l i$ thing." Entertaining Confucianism as it is requires entertaining

\footnotetext{
${ }^{28} \mathrm{I}$ am grateful to an anonymous reviewer for Comparative Philosophy for alerting me to this objection.

${ }^{29}$ It can of course also be objected that there is a parochial set of conventions in philosophy, conventions that, if not customarily polite, function to regulate and establish boundaries for interaction. I will not address this objection here, but have addressed it elsewhere in Olberding 2014, 300.

${ }^{30}$ While I am here not addressing Confucianism in substantive detail, it bears noting that were we more conversant with Confucianism, we would find a host of arguments that compellingly address the power of feedback loops between conduct and intellectual dispositions. Put more strongly, very few Confucians would be prey to just the naivete I identify here, nor would they hold truck with the idea that we can nurture young philosophers to behave one way and define their intellectual interests another.
} 
much that is alien, and of the alien targets Confucianism offers for summary dismissal by western-trained philosophers, li qua etiquette looms largest. My purpose here, to reiterate, is not to rehearse Confucianism. Nonetheless, let me gesture briefly at characteristic elements in its reasoning about manners that are unlikely to find accommodating place in western-dominated philosophical discourse and practice.

I take it as rather a given that ordinary people do care about etiquette and manners. The reasons they care are ones any Confucian philosopher would find familiar. Our prosaic interactions and exchanges with others can exercise an outsized influence on moral well-being, affecting whether, for example, we believe ourselves respected, whether we can achieve fellow feeling and common purpose with others, whether we can cooperate toward shared ends and goods, and whether we steer away from morally corrosive misanthropy and social alienation. Out of reasons such as these, the Confucians count it a high philosophical priority to develop a sophisticated understanding of the link between trained, habitual polite behavior and robust moral goodness.

Perhaps most significantly, the Confucians treat being well-mannered as a way of life. Rather than focusing on problem cases, they attend most to generally reliable yet defeasible guides for social conduct, what Hegel fatuously derided as the Confucian tendency to offer "nothing definite further than a commonplace moral put in the form of good, sound doctrine" (Hegel 1963, 120-121). In this, their aims include discovering what social practices and cultivated habits will most efficaciously fulfill goods such as those limned above - achieving fellow feeling, effective social cooperation, and avoiding misanthropic alienation. While recognizing that no practices or habits can cover all contingencies, they emphasize that much of what matters morally involves behavior and comportment operating beneath conscious awareness and cognitive processing. Thus the "problems" that summon their attention are not isolated situations involving a tension in values requiring deliberate resolution, but challenges concerning shared practices in necessarily imperfect communities, where learners will be subject to environmental shaping and the quality of moral atmosphere a community enjoys will owe much to what its members do reflexively and unthinkingly. ${ }^{31}$ Sussing out mechanisms by which circumspect reflection on deep values can be brought to bear on steering reflex is thus the principal "problem" to solve.

The challenges identified by the Confucians entail that they tarry long in the assailable, focusing effort on capturing both how prosaic courtesy practices most typically work and what personal and social goods they characteristically, if not inevitably, produce. They consequently traverse territories that the contemporary haste to locate and avoid peril will rarely reach. The perils here remain many, but are courted in comprehension that not attending to the moral dynamics of banal social exchanges is the greater danger, for such will leave untouched and uncharted vast reaches of experience that source our moral attitudes, emotions, behaviors, and

\footnotetext{
${ }^{31}$ As I argue elsewhere, this is one reason that Confucian ethics should be of interest for those concerned with the moral aspects of micro-inequities. See Olberding forthcoming.
} 
motivations. Confucianism does not, to be sure, dwell long on answering queries regarding when and whether I may be rude. However, this difference in focus may helpfully alert us to distortions produced where privileging such questions ever forestalls other inquiry, operating as if a precondition for entering any building is knowing first where the exits are and ensuring that they are explicitly marked. Moreover, there is a rational proportionality in the Confucian focus on the generally reliable yet defeasible, a sense that effort expended on the banal and unexceptional is well spent, for it is here that most lives transpire. And, to be sure, there are considerable challenges and difficulties in the unexceptional.

The Confucian sensibility regarding manners comprehends that what we find difficult as moral actors is sometimes, and indeed perhaps most often, managing the unexceptional but unrelenting demands of ordinary life with others. By simple dint of their humanity, others lay claim to our moral energies, requiring acknowledgement and sharing our communal space. How and whether we answer those claims will require much, so devising effective economies, such as those afforded by shared systems of etiquette, is crucial. Above all, they recognize that being polite-that is, being reliably respectful, considerate, and thoughtful in ways that morally profit others and community-is hard. This is in part why their originating exemplar, Confucius, may seem so strikingly different from our own.

Confucius is admired and indeed valorized in his tradition for qualities at considerable odds with at least our most popular, ham-fisted versions of Socrates and, by extension, the social pose we encourage philosophers to adopt. Our Socrates is often presented as a mature version of the child who boldly announces that the emperor has no clothes: He stands ready to bluntly expose the conceits and selfdeceptions by which others operate. Confucius, I expect, would find it meaningful that the traditional version of "The Emperor's New Clothes" features a child, someone, that is, untutored in recognizing the discomfort, shame, and damage where a person is deceived in his own insecurities into parading nude through the streets. The child is naïve, not brave, and mature courage comes in many more, and many more subtle forms than such a tale comprehends. More generally, Confucius is admired in his tradition not least because he is polite, because he gracefully meets the unrelenting challenges of ordinary life. That he is polite is treated not as an incidental fact or feature of personality, but is instead one of the more significant reasons he is counted wise and exemplary. To be a philosopher, in this idiom, is to cultivate deep moral sensitivity to the subtleties of human interaction and the fragility of community constituted through them.

There is much more that might be said, and indeed has been said, about just what is included in Confucianism's ambitious excursions into ordinary good manners and moral goodness, but rehearsing this is beyond my remit. It suffices here to observe that there is much in the style, foci, and practice of early Confucianism that is unlikely to satisfy the expectations of those steeped in the history, discourse conventions, and professional culture I limn above. This is not, on my reckoning, a problem for Confucianism, but for philosophy as it is most often practiced in the contemporary west. That Confucianism may defy our expectations regarding what is 
"philosophically interesting and important" is one potent reason to attend more closely to it and, by extension, to non-western traditions more generally.

I have here only addressed obstacles that might inhibit the capacities of westerntrained philosophers to appreciate one aspect of one of the world's non-western philosophical traditions. However, my more global purpose is to suggest, via this case study, that we modify the ways we in the profession assess efforts at greater inclusivity. Specialists have already produced a substantial body of work that can show why we should care about non-western traditions. What we more urgently need in Anglo-American professional philosophy are far greater efforts at self-scrutiny, efforts to examine why we too often fail to care. Whether or not the westerndominated profession of philosophy can become more inclusive and less indolently incurious about non-western traditions will now most depend on whether it can turn its oft-touted critical spirit on itself, whether it can scrutinize its own assumptions, expectations, and practices. Until this happens, efforts to win greater inclusion for non-western traditions will remain, to borrow phrasing from Mengzi, exercises in climbing trees to search for fish. I have only offered one case study, but I suggest that where we fail to find some substantively core and storied element of a non-western tradition "uninteresting," it's likely us not them.

\section{ACKNOWLEDGEMENTS}

This essay profited from enlivening discussion at the Second Rutgers Conference on Chinese Philosophy, held in 2014, with Tao Jiang, Ruth Chang, Steve Angle, Dean Zimmerman, David Wong, Eric Hutton, and Aaron Stalnaker. I likewise appreciate the helpful and insightful comments provided by two anonymous referees for Comparative Philosophy. Finally, both Garret Olberding and Emily McRae provided invaluable and much appreciated feedback on drafts of this work.

\section{REFERENCES}

Arditi, Jorge (1994), "Hegemony and Etiquette: An Exploration of the Transformation of Practice and Power in Eighteenth Century England," British Journal of Sociology, 45.2: 177-193.

Aristotle (1984), Nichomachean Ethics, in Jonathan Barnes (ed.), The Complete Works of Aristotle, Vol. 2. (Princeton, NJ: Princeton University Press).

Beebee, Helen (2013), "Women and Deviance in Philosophy," in Katrina Hutchinson and Fiona Jenkins (eds), Women in Philosophy: What Needs to Change? (Oxford: Oxford University Press).

Boswell, James (1953) Life of Johnson (Oxford: Oxford University Press, 1953).

Bruya, Brian (forthcoming), "The Tacit Rejection of Multiculturalism in American Philosophy Ph.D. Programs: The Case of Chinese Philosophy," to appear in Dao: A Journal of Comparative Philosophy. 
Buss, Sarah (1999), “Appearing Respectful: The Moral Significance of Manners," Ethics, 109.4: 795-826

Calhoun, Cheshire (2000), "The Virtue of Civility," Philosophy and Public Affairs, 29.3: $251-275$.

Chalmers, David (undated), "Guidelines for Respectful, Constructive, and Inclusive Philosophical Discussion," <http://consc.net/norms.html $>$ (accessed April 24, 2015.)

Cohen, Alix A. (2008), "The Ultimate Kantian Experience: Kant on Dinner Parties," History of Philosophy Quarterly, 25.4: 315-336.

Curtin, Michael (1985), "A Question of Manners: Status and Gender in Etiquette and Courtesy," The Journal of Modern History, 57.3: 395-423.

Dotson, Kristie (2012), "How is this Paper Philosophy?" Comparative Philosophy, 3.1: 3-29 <http://www.comparativephilosophy.org>.

Driver, Julia (2006), "Autonomy and the Asymmetry Problem for Moral Expertise," Philosophical Studies, 128.3: 619-644.

Goffman, Erving (1959), The Presentation of Self in Everyday Life (New York: Anchor Books).

Hamann, Trent (2000), “Modern Etiquette and Foucault's Techniques," International Studies in Philosophy, 32.1: 81-98.

Hegel, G. W. F. (1963), Lectures on the History of Philosophy, trans. E. S. Haldane (New York: Humanities Press).

Heyd, David (1995), "Tact: Sense, Sensitivity, and Virtue," Inquiry, 38.3: 217-231.

Hume, David (1989), Enquiry Concerning the Principles of Morals (Oxford: Clarendon Press).

Kant, Immanuel (2006), Anthropology from a Pragmatic Point of View, eds. Robert B. Louden and Manfred Kuen (Cambridge: Cambridge University Press).

Kristjánsson, Kristján (2006), “Agreeableness," The Journal of Value Inquiry, 40: 3343.

Kupperman, Joel (2002), "Naturalness Revisited: Why Western Philosophers Should Study Confucius," in Bryan W. Van Norden (ed.), Confucius and the Analects: New Essays (New York: Oxford University Press).

Lai, Karyn (2006), " $\mathrm{Li}$ in the Analects: Training in Moral Competence and the Question of Flexibility," Philosophy East and West, 56.1: 69-83.

Li, Chenyang (2000), "Jen and the Feminist Ethics of Care," in Chenyang Li (ed.), The Sage and the Second Sex: Confucianism, Ethics, and Gender (Chicago: Open Court).

Martin, Judith and Gunther S. Ghent (2001), "I Think; Therefore I Thank: A Philosophy of Etiquette," The American Scholar: 237-254.

McGinn, Colin (2013), "Eparter les bourgeois," posted 8/6/2013 <http://mcginn. philospot.com/index.php?story=story130608-115707> (accessed February 2, 2015).

Olberding, Amy (2009), "Ascending the Hall: Demeanor and Moral Improvement in the Analects." Philosophy East and West, 59.4: 503-522. 
Olberding, Amy (2011), Moral Exemplars in the Analects: The Good Person is That (New York: Routledge Press).

Olberding, Amy (2014), "Subclinical Bias, Manners, and Moral Harm," Hypatia, 29.2: $287-302$.

Olberding, Amy (2015), "From Corpses to Courtesy: Xunzi and the Defense of Etiquette," Journal of Value Inquiry, 49: 145-159.

Olberding, Amy (forthcoming), "Etiquette: A Confucian Contribution to Moral Philosophy," Ethics.

Park, Eugene (2014), "Why I Left Academia: Philosophy's Homogeneity Needs Rethinking," Huffington Post, 9/3/2014 <http://www.huffingtonpost.com/hipporeads/why-i-left-academia_b_5735320.html $>$ (accessed February 2, 2015).

Priest, Graham (2006), "What is Philosophy?" Philosophy, 81.316: 189-207.

Rosenlee, Li-Hsiang Lisa (2006), Confucianism and Women: A Philosophical Interpretation (Albany: State University of New York Press).

Rousseau, Jean-Jacques (2012), Discourse on the Science and the Arts, in John T. Scott (ed. and trans.), The Major Political Writings of Jean-Jacques Rousseau (Chicago: University of Chicago Press).

Sarkissian, Hagop (2010a), "Minor Tweaks, Major Payoffs: The Problems and Promise of Situationism in Moral Philosophy," Philosophers' Imprint, 10.9: 1-15.

Sarkissian, Hagop (2010b), "Confucius and the Effortless of Virtue," History of Philosophy Quarterly, 27.1: 1-16.

Sarkissian, Hagop (2014), "Ritual and Rightness in the Analects," in Amy Olberding, ed., Dao Companion to the Analects (New York: Springer Press).

Schmidt, Peter (2014), "The Man who Ranks Philosophy Departments now Rankles Them, too," Chronicle of Higher Education, September 26, $2014<\mathrm{http}: / /$ chronicle. com/article/The-Man-Who-Ranks-Philosophy/149007>(accessed April 24, 2015).

Sherman, Nancy (2005), "Of Manners and Morals," British Journal of Educational Studies, 53.3: 272-289.

Schneewind, J. B. (1998), The Invention of Autonomy (Cambridge: Cambridge University Press).

Slingerland, Edward (2001), "Virtue Ethics, the Analects, and the Problem of Commensurability," Journal of Religious Ethics, 29.1:197-125.

Solomon, Robert (2003), The Joy of Philosophy: Thinking Thin versus the Passionate Life (New York: Oxford University Press).

Stalnaker, Aaron (2013), "Confucianism, Democracy, and the Virtue of Deference," Dao: A Journal of Comparative Philosophy, 12: 441-459.

Stohr, Karen (2006), "Manners, Moral, and Practical Wisdom," in Timothy Chappell, (ed.), Values and Virtue: Aristotelianism in Contemporary Ethics (Oxford: Clarendon Press).

Stohr, Karen (2011), On Manners (New York: Routledge).

Trachtenberg, Zev. (2008), "The Exile and the Moss-Trooper: Rousseau and Thoreau on Walking in Nature," SVEC 2008.03: 209-222.

Van Norden, Bryan W. (2007), Virtue Ethics and Consequentialism in Early Chinese Philosophy (Cambridge: Cambridge University Press). 
Wong, David B. (2008), "If We are not by Ourselves, if We are not Strangers," in Ronnie Littlejohn and Marthe Chandler (eds), Polishing the Chinese Mirror: Essays in Honor of Henry Rosemont, Jr. (New York: Global Scholarly Publications).

Wong, David B. (2014), "Cultivating the Self in Concert with Others," in Amy Olberding (ed.), Dao Companion to the Analects (New York: Springer Press).

Yu, Jiyuan (2007), The Ethics of Confucius and Aristotle: Mirrors of Virtue (New York: Routledge). 